\title{
Asia-Pacific Survey of Physicians on Asthma and Allergic Rhinitis (ASPAIR): physician beliefs and practices about diagnosis, assessment, and treatment of coexistent disease
}

This article was published in the following Dove Press journal:

Journal of Asthma and Allergy

\section{Bhumika Aggarwal' \\ Sumitra Shantakumar ${ }^{2}$ \\ David Hinds ${ }^{3}$ \\ Aruni Mulgirigama ${ }^{4}$}

'Respiratory, Global Classic and Established Products, GSK, Singapore; ${ }^{2}$ Regional Real World Evidence and Epidemiology, GSK, Singapore; ${ }^{3}$ Real World Evidence \& Epidemiology, GSK, Philadelphia, PA, USA; ${ }^{4}$ Respiratory, Global Classic \& Established Products, GSK, London, UK
Correspondence: Bhumika Aggarwal GSK Pte Ltd (Co Regn Number 198102938K), 23 Rochester Park, I 39234 Singapore

Tel +65 6232821 I

Email bhumika.x.aggarwal@gsk.com

\begin{abstract}
Background: Asthma and allergic rhinitis (AR) frequently coexist, and having both asthma and AR is associated with uncontrolled asthma and a heavier disease burden. The Asia-Pacific Survey of Physicians on Asthma and Allergic Rhinitis (ASPAIR) aimed to assess physicians' perceptions and their management practices for patients with coexistent disease.

Materials and methods: A total of 1,204 general physicians and pediatricians from six countries in Asia, who routinely treat asthma patients, were interviewed in-person. Physicians were questioned about their attitudes and beliefs of coexistent asthma-AR, how they diagnose and treat patients, and their knowledge of international guideline recommendations.

Results: Physicians reported that $45 \%$ of their patients with asthma have coexistent AR and $37 \%$ of their patients with AR have coexistent asthma. Most physicians (77\%) agreed that coexistent asthma-AR is a genuine condition and that patients suffer worse symptoms with both the conditions vs one alone (86\%). Although nearly all agreed that both asthma and AR should be treated (91\%) and that intranasal (INS) and inhaled corticosteroids (ICS) could be given concurrently to these patients, $40 \%$ also thought that treating both conditions effectively at the same time is difficult, and approximately a quarter believed that corticosteroid therapy should be delayed in children for both asthma and AR. While there was universal recognition and acceptance that guidelines provide sufficient information for treating uncontrolled coexistent disease $(\geq 80 \%$ physicians in all countries), physicians revealed that $41 \%$ of their asthma patients are treated with short-acting rescue medications alone, and only $47 \%$ responded that treatment with concurrent INS and ICS, as recommended in the Allergic Rhinitis and its Impact on Asthma (ARIA) guidelines, was their preferred treatment for coexistent disease.

Conclusion: The ASPAIR survey demonstrates a widespread acceptance of coexistent asthma$\mathrm{AR}$, and the associated burden, but highlights the need for increased healthcare practitioner communication and awareness to improve appropriate treatment and management of these coexistent conditions.
\end{abstract}

Keywords: asthma, allergic rhinitis, coexistent asthma-AR, Asia-Pacific, ASPAIR survey

\section{Introduction}

Asthma and allergic rhinitis (AR) are both chronic inflammatory diseases of the airways and may share a common pathophysiology. ${ }^{1,2}$ They frequently coexist with as many as $80 \%$ of asthma patients reported to have AR and $\sim 15 \%-40 \%$ of AR patients reported to have asthma. ${ }^{3-6}$ Rhinitis is a significant risk factor for adult-onset asthma ${ }^{3,7,8}$ and, compared with asthma alone, patients with coexistent asthma-AR are more likely to have uncontrolled asthma, ${ }^{3,9-11}$ experience a greater number of asthma attacks, ${ }^{12-14}$ 
and report worse quality of life. ${ }^{15,16}$ Although there has been a high prevalence of coexistent asthma-AR reported in some low- and middle-income countries, consistent with that reported in higher income countries, ${ }^{3,17-19}$ there is a potential for underdiagnosis and suboptimal management of coexistent disease in low- and middle-income countries, possibly related to a lack of awareness and low public health prioritization in relation to these diseases. ${ }^{17,20,21}$

The Allergic Rhinitis and its Impact on Asthma (ARIA) guidelines recommend that patients with persistent AR should be routinely evaluated for asthma, and patients with asthma should be assessed for rhinitis. ${ }^{3}$ The guidelines also recommend a combined strategy for treating the upper and lower airways, citing the co-administration of intranasal (INS) and inhaled corticosteroids (ICS) as the most effective medications for coexistent asthma-AR. ${ }^{3}$ The ARIA guidelines are cited in the Global Initiative for Asthma (GINA) report where coexistent AR with asthma is identified as a contributor towards suboptimal symptom control. ${ }^{22}$ However, GINA places less emphasis on the importance of a combined strategy to treat the coexistent asthma-AR, ${ }^{22}$ vs the ARIA guidelines which recommend treatment with INS and ICS, suggesting a lack of consistency between the two sets of recommendations.

Previously, the Asthma Insights and Managements surveys reported an underuse of ICS to treat asthma together with an overuse of oral steroids in the Asia-Pacific region compared with the US, Canada, and Europe. ${ }^{23}$ Knowledge gaps in the management of coexistent asthma-AR were also highlighted in a recent cross-sectional survey of physicians in China, in which a fifth of those surveyed reported the use of oral leukotriene antagonists as the most commonly used drug for treating AR while also controlling asthma. ${ }^{24}$

Considering the diversity of treatment practice, the Asia-Pacific Survey of Physicians on Asthma and Allergic Rhinitis (ASPAIR) study aimed to assess physician attitudes and beliefs about coexistent asthma-AR, together with their management and treatment practices, across six countries. This paper describes the core results for the total physician population sampled.

\section{Materials and methods}

\section{Study design and participants}

This was a cross-sectional survey of general physicians (primary care and hospital-based) and pediatricians who routinely treated adult and/or pediatric asthma patients (at least 10 month), in China, India, Malaysia, the Philippines,
Thailand, and Vietnam (GSK Study 206753). Physician specialists (respiratory and non-respiratory) were excluded. In China, all levels of care, including primary care, are provided in hospital/clinic settings; therefore, all physicians were hospital-based general practice/internal medicine physicians, consistent with primary care physicians in other countries.

A probability-based sampling methodology was used to obtain a representative national sample of physicians across regions in each country, comprising $\sim 200$ physicians per country (50\% general physicians and 50\% pediatricians) giving a total sample size of 1,204. At selected sites, physicians were identified randomly using a number generator with the aim of obtaining four completed interviews out of 16 physicians identified. A maximum number of four completed interviews (two general physicians and two pediatricians) were allowed per facility.

The survey protocol and consent procedure were reviewed by an institutional review board, and this study was granted an exemption as the criteria for exemption were met under 45 CFR 46.101.(b)(2) of the US Code of Federal Regulations. The protocol included an Adverse Event protocol (no issues events were reported), data safety plan to ensure confidentiality and data safety, voluntary consent, disclosure of the survey sponsor, and informed right to withdraw at the end of the survey.

\section{Questionnaire}

A standardized questionnaire was developed with key external and local country experts and covered the following topics: attitudes and beliefs about coexistent asthma-AR, management and treatment practices for these patients, and knowledge and adherence to GINA and ARIA guidelines. The survey was administered via face-to-face interviews in the local language using Computer-Assisted Personal Interviewing tablets or laptops. Physicians were asked the questions by a professional interviewer and took the format of a multiple-choice list of answers from which to choose, an open-ended question with no specified list of answers, or response using a 5-point Likert scale (ranging from "strongly agree" to "strongly disagree"). The average interview length was 31 minutes (range 28 minutes [India] to 33 minutes [Philippines]), and the response rate by country ranged from $51 \%$ (India) to $72 \%$ (Malaysia).

\section{Data analysis}

Descriptive data summarizing physician responses are presented as unadjusted means, medians, frequencies, 
and/or proportions. Physician responses are presented as unadjusted statistics to be reflective of the full sampled populations. These physician sample data are not weighted because standardized and reliable estimates of the key demographic parameters of the universe of physicians in each country were not readily available and were not weighted overall due to the disproportionate size of countries.

Comparisons of demographic characteristics between countries were analyzed using a Z-test or Fisher's exact test for counts with $n \leq 5$. The Kruskal-Wallis non-parametric test was used to compare physicians' preferred treatment for coexistent asthma-AR, testing against an expected equal distribution of cases across countries. All tests were conducted using IBM SPSS Statistics software.

\section{Results \\ Physician demographics}

In the total sample of physicians across all six countries, over half were female physicians (53\%), consistent across countries except India (25\%) (Table 1). There was generally an equal distribution across the working population ages, but age distribution varied across countries. There was a higher proportion of younger physicians in Malaysia and Vietnam ( $>70 \%$ in each country were younger than 45 years) and a quarter of physicians in India and the Philippines were older than 55 years. Sixty eight percent of physicians were hospital-based with the highest proportion of hospital physicians observed in China (100\%; a factor of the healthcare system) and Thailand (86\%). Other countries had a more even distribution between clinic-based and hospital-based physicians. In each country, only a small proportion of physicians worked in government clinics $(\leq 14 \%)$ apart from Vietnam (38\%). For the whole sample, the mean number of years worked in clinical practice was 15.5 years, which was broadly similar across countries. Most physicians had received some form of additional training in the management of asthma and AR, but the proportion was higher in relation to asthma (83\%) vs AR (68\%), similar in the six countries surveyed. Statistically significant differences in demographic characteristics between countries are summarized in Table 1.

\section{Beliefs and practices about coexistent asthma-AR and its diagnosis}

Overall, physicians reported $45 \%$ of their asthma patients as having coexistent AR (range $34 \%-50 \%$ ) and $37 \%$ of their AR patients as having coexistent asthma (range
$28 \%-46 \%$ ). While $77 \%$ of physicians surveyed strongly or somewhat agreed that coexistent asthma-AR is a genuine condition with therapeutic consequences (range $67 \%-85 \%$ ), more than a quarter of physicians sampled in India, the Philippines, and Vietnam strongly or somewhat agreed that patients with coexistent disease do not require different treatment to patients with one condition (Figure $1 \mathrm{~A}$ and $\mathrm{B})$.

Approximately $70 \%$ of physicians confirmed that they questioned their asthma patients about AR symptoms and their AR patients about symptoms of asthma at every clinic visit. Physicians in all countries most commonly assessed the history of nasal symptoms to diagnose AR in asthma patients (88\%, range $74 \%-100 \%)$ (Table S1). History of eye symptoms (50\%) was commonly used in Thailand $(78 \%)$ and India $(75 \%)$ and least cited by physicians in the Philippines (8\%) and Vietnam (17\%), and family history of AR (47\%) was used by $>50 \%$ of physicians in China, India, and Thailand but cited by just $16 \%$ of physicians in Vietnam. Similarly, in all countries, the most common criterion physicians used to diagnose asthma in AR patients was symptoms of asthma (91\%, range $78 \%-100 \%$ ). A family history of asthma was also commonly used by the physicians interviewed in China, India, and Thailand ( $>70 \%$ of physicians) but was less common in Vietnam (28\%), Malaysia (31\%), and the Philippines (34\%). Approximately a third of physicians measured lung function to diagnose asthma, most frequently physicians interviewed in China (57\%) and Thailand (50\%) but only $5 \%$ of physicians questioned in the Philippines and $17 \%$ in Malaysia (Table S1).

\section{Assessment of asthma control}

When assessing asthma control in patients with coexistent asthma-AR, physicians in all countries surveyed used the type and frequency of symptoms most commonly (84\%; range $72 \%-92 \%$ ) (Table S2). Other responses showed different trends across countries; for example, number of nighttime awakenings was used by over half of the physicians surveyed in India (63\%), China (55\%), and Thailand (52\%), but by only $4 \%$ and $7 \%$ of physicians in Vietnam and the Philippines, respectively. Physicians in Thailand also considered the number of exacerbations and negative impacts on daily activities as important criteria for assessing control (reported by $66 \%$ and $65 \%$ of physicians, respectively). Of note, monitoring the frequency of shortacting beta-agonist (SABA) use to assess asthma control was consistently low in all participating countries (11\%), 
Table I Demographic characteristics of physicians by country

\begin{tabular}{|c|c|c|c|c|c|c|c|}
\hline & $\begin{array}{l}\text { Total } \\
N=1,204\end{array}$ & $\begin{array}{l}\text { China } \\
N=200 \\
\text { (A) }\end{array}$ & $\begin{array}{l}\text { India } \\
N=200 \\
\text { (B) }\end{array}$ & $\begin{array}{l}\text { Malaysia } \\
\mathrm{N}=202 \\
\text { (C) }\end{array}$ & $\begin{array}{l}\text { Philippines } \\
\mathrm{N}=\mathbf{2 0 0} \\
\text { (D) }\end{array}$ & $\begin{array}{l}\text { Thailand } \\
\mathbf{N}=\mathbf{2 0 0} \\
\text { (E) }\end{array}$ & $\begin{array}{l}\text { Vietnam } \\
N=202 \\
(F)\end{array}$ \\
\hline \multicolumn{8}{|l|}{ Age (years) } \\
\hline$(n=327)$ & 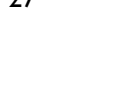 & 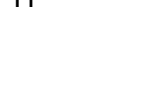 & 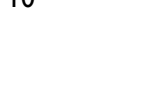 & $\begin{array}{l}\mathrm{ABD} * * * \\
\mathrm{E}^{* *}\end{array}$ & 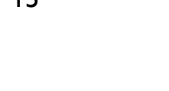 & $\mathrm{ABD} * * *$ & $\mathrm{ABDE}^{* * *}$ \\
\hline $35-44$ & 31 & 43 & 34 & 25 & 33 & 29 & 22 \\
\hline$(n=372)$ & & $\begin{array}{l}C F * * * \\
E^{* *} D^{*}\end{array}$ & $\mathrm{~F}^{*}$ & & $\mathrm{~F}^{*}$ & & \\
\hline $45-54$ & 26 & 35 & 33 & 16 & 27 & 26 & 17 \\
\hline$(n=309)$ & & $\begin{array}{l}\mathrm{CF}^{* * * *} \\
\mathrm{E}^{*}\end{array}$ & $\mathrm{CF}^{* * *}$ & & C**F* & $\mathrm{CF}^{* *}$ & \\
\hline $55-64$ & 13 & 10 & 18 & 5 & 19 & 16 & 9 \\
\hline$(n=153)$ & & & $\mathrm{C}^{* * *}$ & & & C** & \\
\hline & 3 & I & $\begin{array}{l}A r^{-1} \\
7\end{array}$ & 3 & 6 & $\begin{array}{l}r^{*} \\
-\end{array}$ & I \\
\hline$(n=35)$ & NT & NT & NT & NT & NT & NT & NT \\
\hline \multicolumn{8}{|l|}{ Gender } \\
\hline $\begin{array}{l}\text { Male } \\
(n=566)\end{array}$ & 47 & 34 & $\begin{array}{l}76 \\
\mathrm{ACDEF} * * *\end{array}$ & $\begin{array}{l}48 \\
A D^{* *}\end{array}$ & 32 & $\begin{array}{l}43 \\
D^{*}\end{array}$ & $\begin{array}{l}50 \\
D^{* * * *}\end{array}$ \\
\hline $\begin{array}{l}\text { Female } \\
(n=638)\end{array}$ & 53 & $\begin{array}{l}66 \\
\mathrm{~B}^{* * *} \\
\mathrm{CF} * * \\
\end{array}$ & 25 & $\begin{array}{l}52 \\
\mathrm{~B}^{* * *}\end{array}$ & $\begin{array}{l}69 \\
\mathrm{BF}^{* * *} \\
\mathrm{C}^{* *} \mathrm{E}^{*}\end{array}$ & $\begin{array}{l}57 \\
\mathrm{~B} * * *\end{array}$ & $\begin{array}{l}A^{*} \\
50 \\
B^{* * *}\end{array}$ \\
\hline $\begin{array}{l}\text { Type of practice } \\
\text { Government clinic/ } \\
\text { office } \\
(n=155)\end{array}$ & 13 & 0 & $\begin{array}{l}6 \\
A^{* * *}\end{array}$ & 9 & $\begin{array}{l}14 \\
\mathrm{~A}^{* * *} \\
\mathrm{~B}^{* *}\end{array}$ & $\begin{array}{l}\text { II } \\
\mathrm{A}^{* * *}\end{array}$ & $\begin{array}{l}38 \\
\mathrm{ABCDE} * * *\end{array}$ \\
\hline $\begin{array}{l}\text { Government hospital } \\
(n=598)\end{array}$ & 50 & $\begin{array}{l}98 \\
\mathrm{BCDEF} * * *\end{array}$ & $\begin{array}{l}29 \\
D^{*}\end{array}$ & $\begin{array}{l}35 \\
D * * *\end{array}$ & 19 & $\begin{array}{l}70 \\
\mathrm{BCDF} * * *\end{array}$ & $\begin{array}{l}49 \\
\mathrm{BD}^{* * *} \\
\mathrm{C} * *\end{array}$ \\
\hline $\begin{array}{l}\text { Private clinic/office } \\
(n=234)\end{array}$ & 19 & 0 & $\begin{array}{l}32 \\
\mathrm{AEF} * * *\end{array}$ & $\begin{array}{l}43 \\
\mathrm{AEF}^{* * *} \\
\mathrm{~B}^{\mathrm{a}}\end{array}$ & $\begin{array}{l}35 \\
\mathrm{AEF} * * *\end{array}$ & $\begin{array}{l}5 \\
\mathrm{~A}^{* *}\end{array}$ & $\begin{array}{l}3 \\
A^{*}\end{array}$ \\
\hline $\begin{array}{l}\text { Private hospital } \\
(\mathrm{n}=217)\end{array}$ & 18 & 3 & $\begin{array}{l}34 \\
\mathrm{ACEF} * * *\end{array}$ & $\begin{array}{l}13 \\
A^{*}\end{array}$ & $\begin{array}{l}33 \\
\mathrm{ACEF} * * *\end{array}$ & $\begin{array}{l}16 \\
A^{* * *}\end{array}$ & $\begin{array}{l}\text { II } \\
A^{* *}\end{array}$ \\
\hline \multicolumn{8}{|l|}{$\begin{array}{l}\text { Years in clinical } \\
\text { practice }\end{array}$} \\
\hline Mean & 15.5 & $\begin{array}{l}19.4 \\
C E F * * * \\
D^{* *}\end{array}$ & $\begin{array}{l}19.7 \\
C E F * * * \\
D^{* *}\end{array}$ & 12.0 & $\begin{array}{l}16.1 \\
C F^{* * *} \\
E^{*}\end{array}$ & $\begin{array}{l}\mathrm{I4.0} \\
\mathrm{CF} *\end{array}$ & 11.9 \\
\hline Median & 14 & 20 (SD 7.8) & I8 (SD I0.4) & 9 (SD 9.4) & 15 (SD I0.7) & I3 (SD 9.1) & $9(10.2)$ \\
\hline \multicolumn{8}{|l|}{$\begin{array}{l}\text { Continuing } \\
\text { medical education }\end{array}$} \\
\hline $\begin{array}{l}\text { Asthma management } \\
\text { and treatment } \\
(n=I, 000)\end{array}$ & 83 & $\begin{array}{l}89 \\
\mathrm{BE}^{* *}\end{array}$ & 77 & $\begin{array}{l}85 \\
E^{*}\end{array}$ & $\begin{array}{l}89 \\
\mathrm{BE}^{* *}\end{array}$ & 76 & 84 \\
\hline $\begin{array}{l}\text { AR management and } \\
\text { treatment }(n=8 \mid 8)\end{array}$ & 68 & $\begin{array}{l}72 \\
C * * *\end{array}$ & $\begin{array}{l}70 \\
C^{* * *}\end{array}$ & 53 & $\begin{array}{l}85 \\
C E F * * * \\
A B^{* *}\end{array}$ & $\begin{array}{l}66 \\
C^{*}\end{array}$ & $\begin{array}{l}63 \\
C^{*}\end{array}$ \\
\hline
\end{tabular}

Notes: Values shown as $\%$ unless stated otherwise. ${ }^{*} P<0.05$, ${ }^{* * P}<0.01$, $* * * P<0.001$ ( $95 \%$ confidence level).

Abbreviation: NT, not tested due to small sample size; SD, standard deviation.

with physicians interviewed in India reporting the most frequent use (24\%). Similarly, the use of patient-reported outcome (PRO) tools was also low (8\%, range 1\%-20\%). On the other hand, $16 \%$ of physicians used patient/family feedback to monitor asthma control, and this was most commonly reported by physicians questioned in China (43\%) and Thailand (30\%) (Table S2). When asked about assessing asthma control in patients with asthma only, overall responses showed some similarities but were not entirely consistent; for example, physicians more commonly used 
A Q. Asthma and allergic rhinitis can coexist and could have specific therapeutic consequences.

- Strongly disagree

- Somewhat disagree

Neutral

- Somewhat agree

- Strongly agree

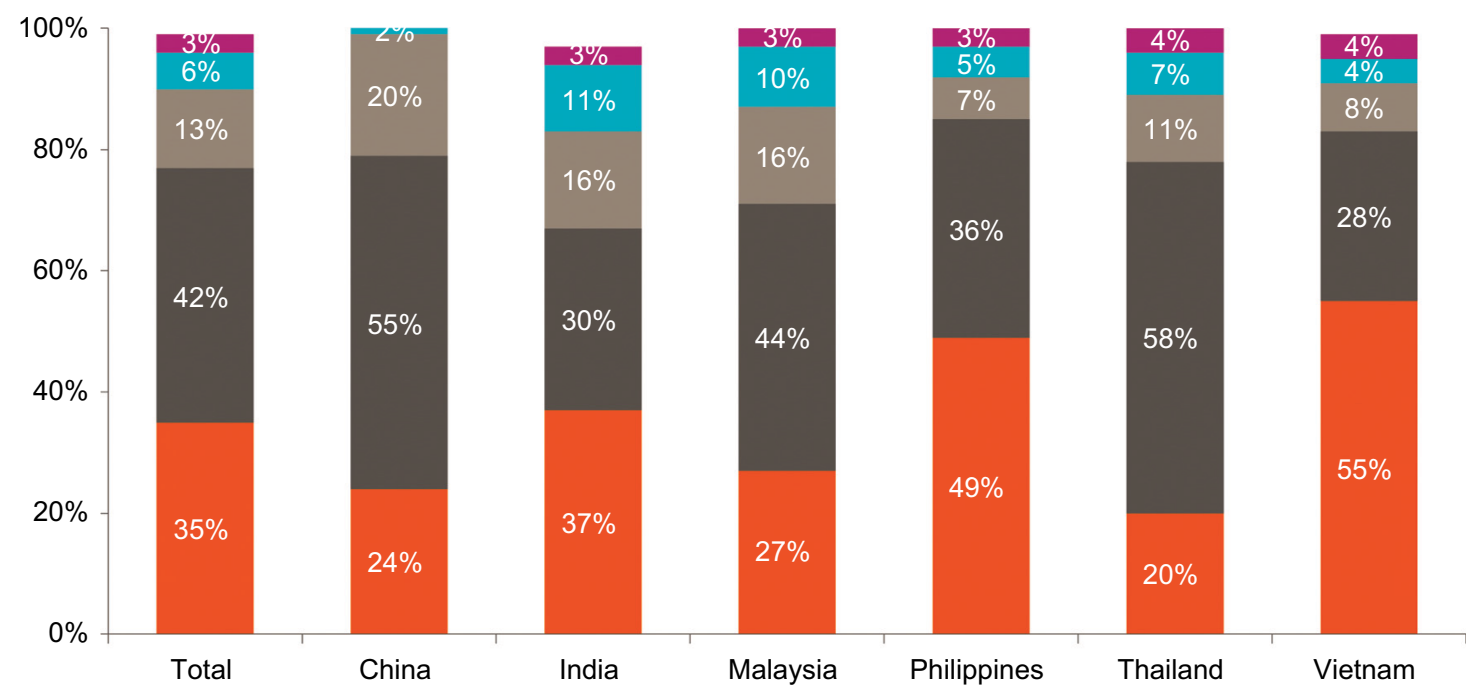

B Q. Co-existent asthma-allergic rhinitis does not matter — in the end patients receive the same treatment

— Strongly disagree

- Somewhat disagree

Neutral

- Somewhat agree

- Strongly agree

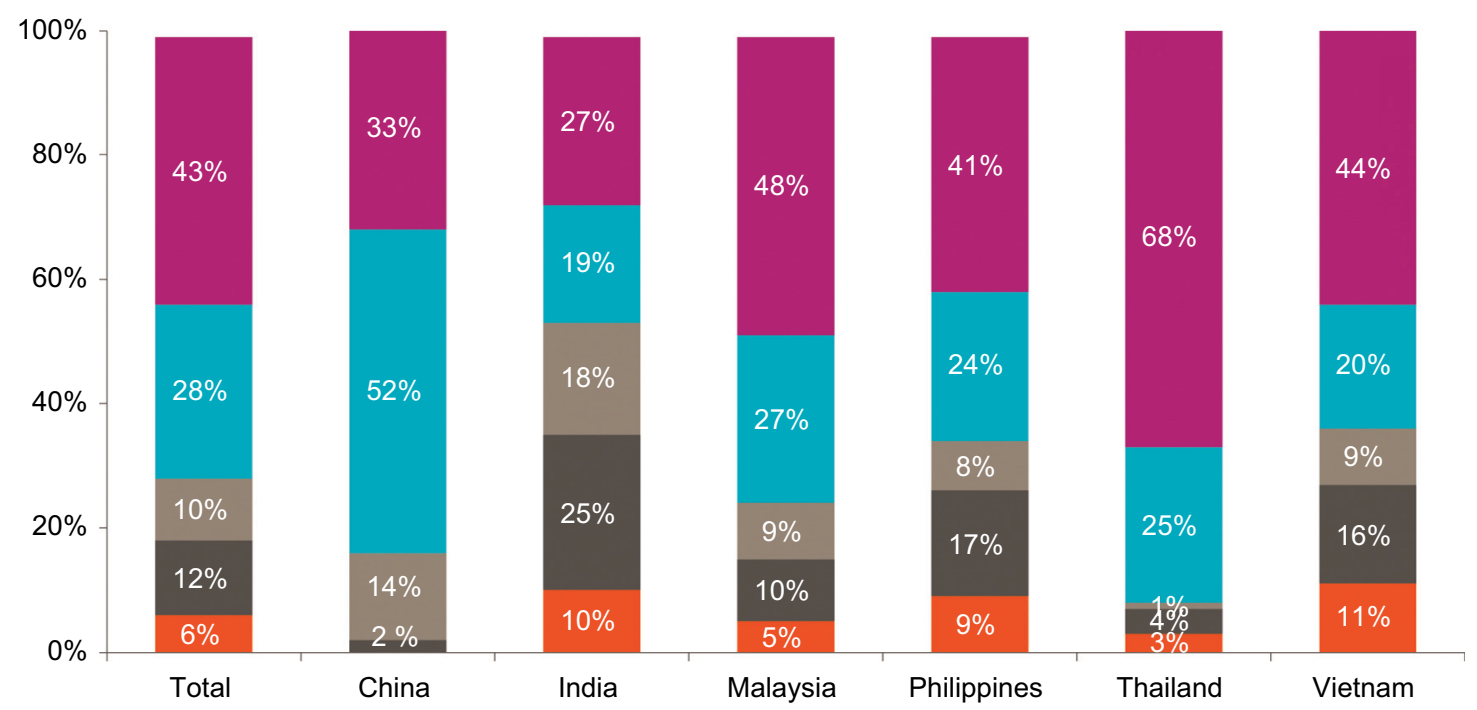

Figure I (A) Physician beliefs about the existence of coexistent asthma-AR. (B) Physician beliefs about the importance of treating coexistent asthma-AR.

Notes: Total $(n=1,204)$, China $(n=200)$, India $(n=200)$, Malaysia $(n=202)$, Philippines $(n=200)$, Thailand $(n=200)$, Vietnam $(n=202)$. Percentages for specific responses $<1 \%$, not shown.

Abbreviation: AR, allergic rhinitis. 
frequency of nighttime awakenings (49\%), frequency of SABA use (30\%), and use of PRO tools (18\%) (Table S3).

\section{Physician perceptions about the impacts of coexistent asthma-AR on patients}

Most physicians strongly or somewhat agreed that coexistent disease results in patients having worse asthma symptoms (86\%, range $83 \%-92 \%)$ and worse AR symptoms $(77 \%$, $65 \%-87 \%$ ), compared with either condition alone. Similarly, more than $80 \%$ of physicians reported that patients with both the conditions are more negatively affected by worse sleep and disrupted daily activities, and this high impact was broadly consistent across countries (Figure 2A and B). However, a greater proportion of physicians interviewed reported that patients with asthma alone vs coexistent disease are more likely to have frequent unplanned clinic or emergency room visits ( $44 \%$ vs $42 \%$ ) or hospitalizations due to an uncontrolled disease (56\% vs 40\%) (Figure 3A and B). This pattern was similar across countries except for China where physicians reported that patients with coexistent asthma-AR are most likely to require additional, unplanned healthcare visits or hospitalization due to an uncontrolled disease vs either condition alone (Figure 3A and B).

\section{Beliefs and practices about the management and treatment of coexistent asthma-AR}

While most physicians answered "yes" to the question "do the guidelines provide sufficient information for treating a patient with uncontrolled coexistent asthma-allergic rhinitis?" ( $\geq 80 \%$ of physicians in all countries other than Malaysia [67\%]), just less than half of all surveyed physicians strongly or somewhat agreed that the disease was not well-defined (44\%, range $28 \%$ [China] to $60 \%$ [Vietnam]). Similarly, although most physicians strongly or somewhat agreed that both the conditions should be managed and treated (91\%; range $85 \%-98 \%$ ), two fifths of physicians strongly or somewhat agreed that it was difficult to effectively treat them at the same time ( $40 \%$, range $23 \%$ [Thailand] to $59 \%$ [India]). In practice, $75 \%$ of physicians said that they manage both the conditions in patients with coexistent disease ( $76 \%$, range $61 \%$ [India] to $91 \%$ [Thailand]); however, approximately a third of physicians interviewed in India, Malaysia, and Vietnam preferentially managed one condition (Figure 4). Physicians surveyed in Vietnam (87\%), the Philippines (61\%), and India (55\%) generally strongly or somewhat agreed with the statement "Managing and treating the more severe of conditions of coexistent asthma-allergic rhinitis is sufficient." Referrals to specialists were relatively low across all countries. Even for patients with uncontrolled coexistent asthma-AR, 39\% of physicians stated that they would modify the patients' treatment themselves rather than refer to a specialist (range 29\% [China] to $46 \%$ [Philippines]). In addition, $46 \%$ of physicians considered their patient to be "well managed" if the patient reported an improvement in either condition (range 10\%-73\%), and this belief was most commonly expressed by physicians surveyed in India (65\%) and the Philippines (73\%).

With respect to treatment for asthma, many physicians revealed that their asthma patients are treated with a SABA alone (41\%), least commonly reported by physicians interviewed in Thailand (23\%) and most commonly reported by physicians interviewed in Vietnam (55\%). Among physicians prescribing controller medications, the most commonly prescribed were ICS (72\% of physicians prescribing additional medication; range 34\% [Philippines] to $90 \%$ [China and Thailand]) followed by leukotriene receptor antagonists (LTRA) (59\%; range 43\% [Malaysia] to $80 \%$ [China]), and ICS/long-acting beta-agonists (46\%, range 11\% [Philippines and Vietnam] to 79\% [Thailand]) (response options were not read from a list).

Regarding treatment for coexistent asthma-AR, most physicians agreed (answered "yes") that additional medications are needed, compared with treating one condition alone ( $89 \%$, range $82 \%-94 \%$ ), and $83 \%$ of physicians responded that this involved prescribing treatment for both asthma and AR, consistently shown across countries except for India (51\%). Although most physicians strongly or somewhat agreed that ICS and INS could be given concurrently to patients with asthma and AR, respectively $(82 \%$, range $68 \%$ [India] to $88 \%$ [Thailand]), $46 \%$ strongly or somewhat agreed that treating both the diseases required too much medication and $37 \%$ strongly or somewhat agreed that ICS therapy was associated with too many side effects. These concerns were particularly common in physicians surveyed in India ( $\geq 80 \%$ ) and Vietnam $(\geq 60 \%)$, and these beliefs were reflected in the treatments that the physicians had prescribed. The most commonly prescribed treatment (chosen from a given list) was a combination of ICS and INS ( $47 \%$ of physicians), with physicians interviewed in China most likely to prescribe this treatment (71\%) and physicians interviewed in India, the Philippines, and Vietnam least likely ( $\leq 40 \%$ of physicians) $(P<0.001$ for statistical difference across countries; Table 2$)$. Other prescribed medications included a combination of oral LTRA and ICS (22\%, range $6 \%$ [China] to 36\% [(Vietnam]) and ICS and oral antihista- 
A Q. To what extent do you believe coexistent asthma-allergic rhinitis negatively impacts sleep compared to having only one condition?

- A lot worse

- Somewhat worse

About the same

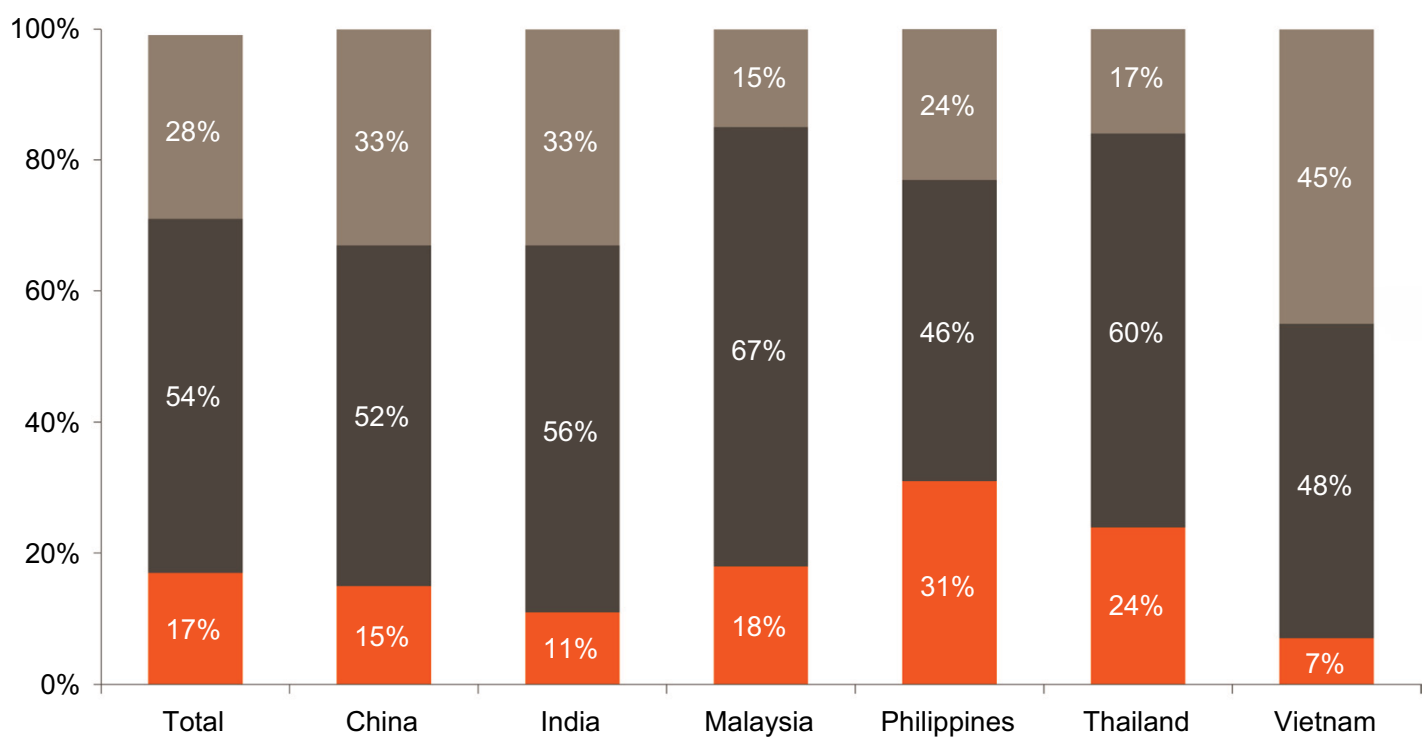

B Q. To what extent do you believe coexistent asthma-allergic rhinitis negatively impacts school, work, and daily activities compared to having only one condition?

A lot worse

- Somewhat worse

About the same

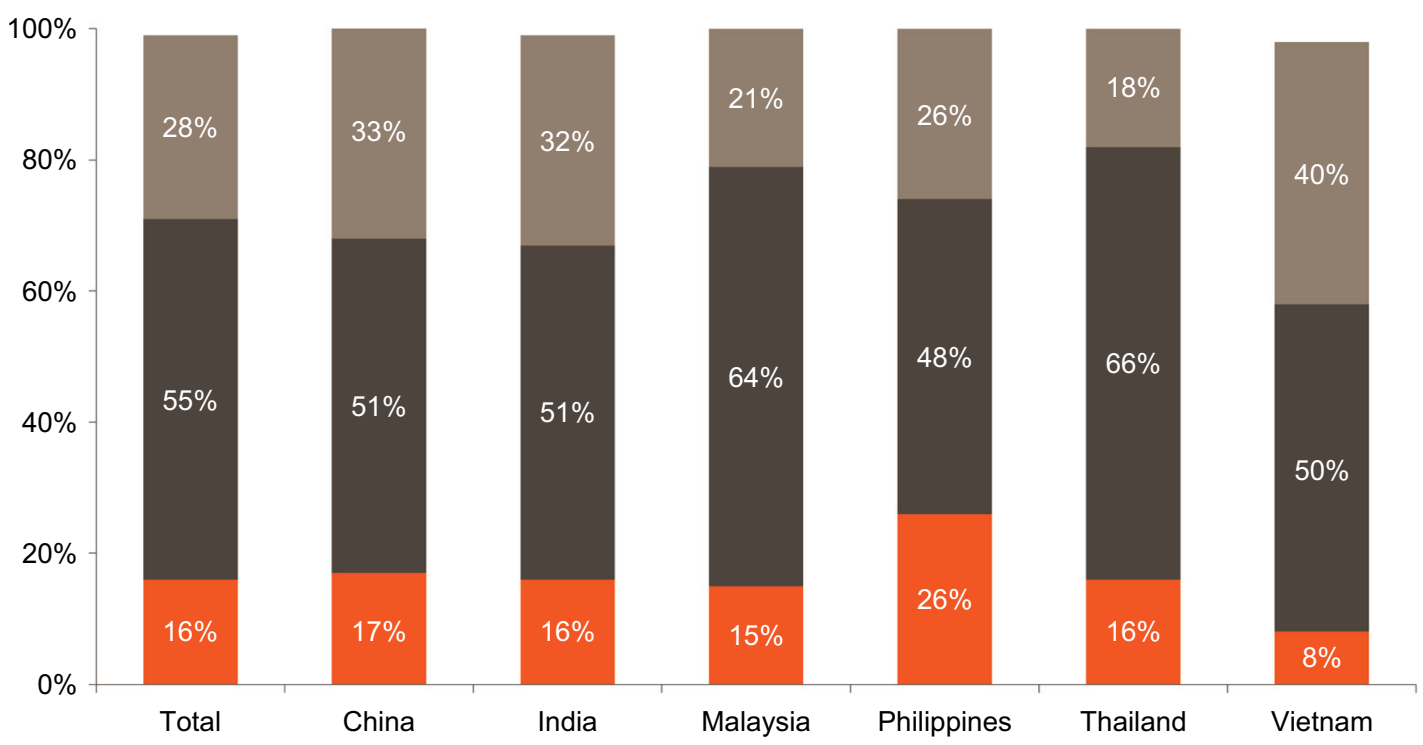

Figure 2 Impact of coexistent asthma-AR on (A) sleep and (B) daily activities.

Note: Total $(n=1,204)$, China $(n=200)$, India $(n=200)$, Malaysia $(n=202)$, Philippines $(n=200)$, Thailand $(n=200)$, Vietnam $(n=202)$.

Abbreviation: $A R$, allergic rhinitis. 
A Q. Which patients are more likely to have frequent unplanned clinic, office, or ER visits?

- Asthma patients

- Allergic rhinitis patients

- Asthma and allergic rhinitis patients

- No difference

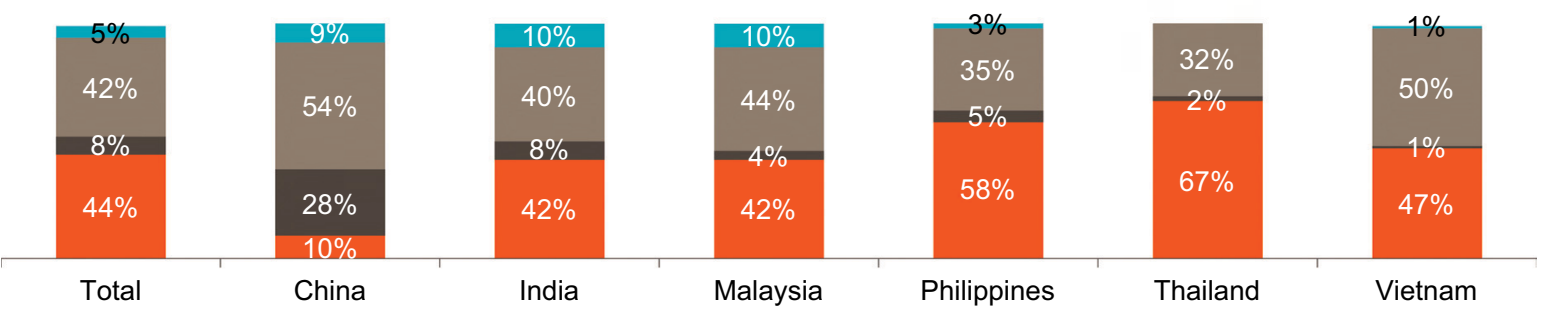

B Q. Which patients are more likely to have hospitalizations for an uncontrolled disease?

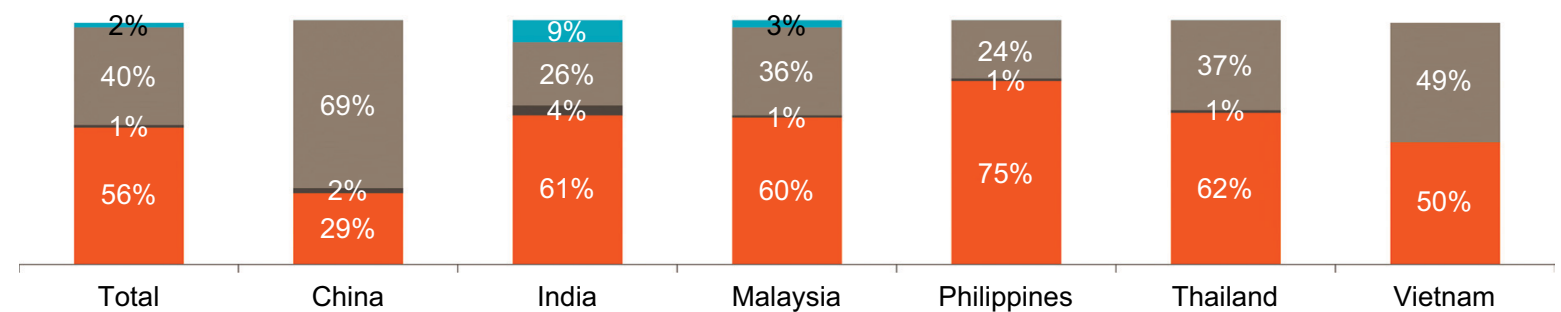

Figure 3 Relative impact of asthma, AR, and coexistent asthma-AR on healthcare resource use: (A) frequent unplanned clinic or emergency room visits and (B) hospitalizations for an uncontrolled disease.

Note: Total $(n=1,204)$, China $(n=200)$, India $(n=200)$, Malaysia $(n=202)$, Philippines $(n=200)$, Thailand $(n=200)$, Vietnam $(n=202)$. Percentages for specific responses $<1 \%$, not shown.

Abbreviations: AR, allergic rhinitis; ER, emergency room.

Q. How do you manage patients with coexistent asthma-allergic rhinitis? Do you...?

- Manage only one condition

Manage the more troublesome condition first followed by the other

Mange both simultaneously

- Manage asthma on a long-term basis and allergic rhinitis symptomatically OR

Refer these patients to an allergist and/or pulmonologist or ENT

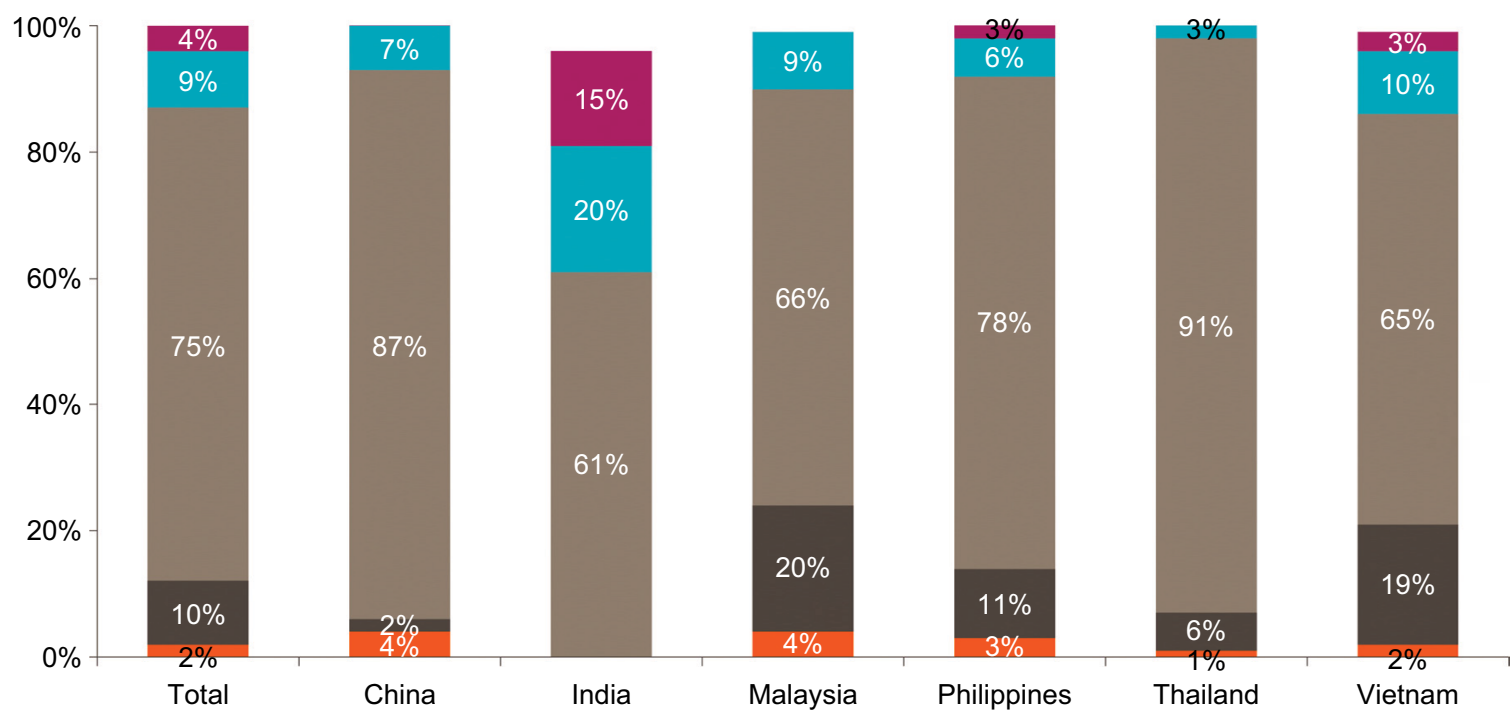

Figure 4 Management of coexistent asthma-AR.

Notes: Total $(n=1,204)$, China $(n=200)$, India $(n=200)$, Malaysia $(n=202)$, Philippines $(n=200)$, Thailand $(n=200)$, Vietnam $(n=202)$. Percentages for specific responses $<1 \%$, not shown.

Abbreviations: AR, allergic rhinitis; ENT, ear-nose-throat specialist. 
mines (15\%, range 5\% [China] to 23\% [Malaysia]) (Table 2). Approximately, a quarter of physicians surveyed strongly or somewhat agreed that, in children, ICS should be delayed for asthma (24\%, range $7 \%$ [Thailand] to $36 \%$ [India]) and INS should be delayed for AR (25\%; range 7\% [Thailand] to $38 \%$ [Vietnam]), with $\geq 30 \%$ of physicians interviewed in China, India, and Vietnam expressing this view.

When questioned about what influences their treatment choice for patients with coexistent asthma-AR (openended question), use of practice guidelines was the most frequently reported $(62 \%)$, with patient affordability $(50 \%)$ and physician experience (49\%) also commonly reported (Table 3). This varied across countries; for example, few physicians interviewed in the Philippines used guidelines (17\%), affordability being the biggest consideration (70\%), and $63 \%$ of the physicians interviewed in China relied on their own personal experience. More than half of all physicians interviewed (58\%) strongly or somewhat agreed that taking therapy for both the conditions was inconvenient for patients (range $42 \%$ [Thailand] to $80 \%$ [Vietnam]) and
$46 \%$ of physicians strongly or somewhat agreed that their patients prefer to take oral medications over inhalers and nasal sprays (range 29\% [Thailand] to 58\% [Philippines]) (Figure 5).

\section{Discussion}

The ASPAIR survey provides an opportunity to understand the views of physicians in the Asia-Pacific region with respect to coexistent asthma-AR, their beliefs about the individual conditions, and their knowledge of international guidelines with respect to managing coexistent disease. Overall, most physicians interviewed across the six countries strongly or somewhat agreed that asthma and AR can coexist, with its associated impacts on patients, and the need to manage and treat both the conditions. In addition, most physicians surveyed acknowledged the acceptability of the guidelines; however, when applying the guidelines, physicians frequently did not follow through the recommendations in terms of assessing both asthma control and preferred treatments.

Q. Patients prefer oral medication over inhalers and nasal sprays for their asthma and allergic rhinitis.

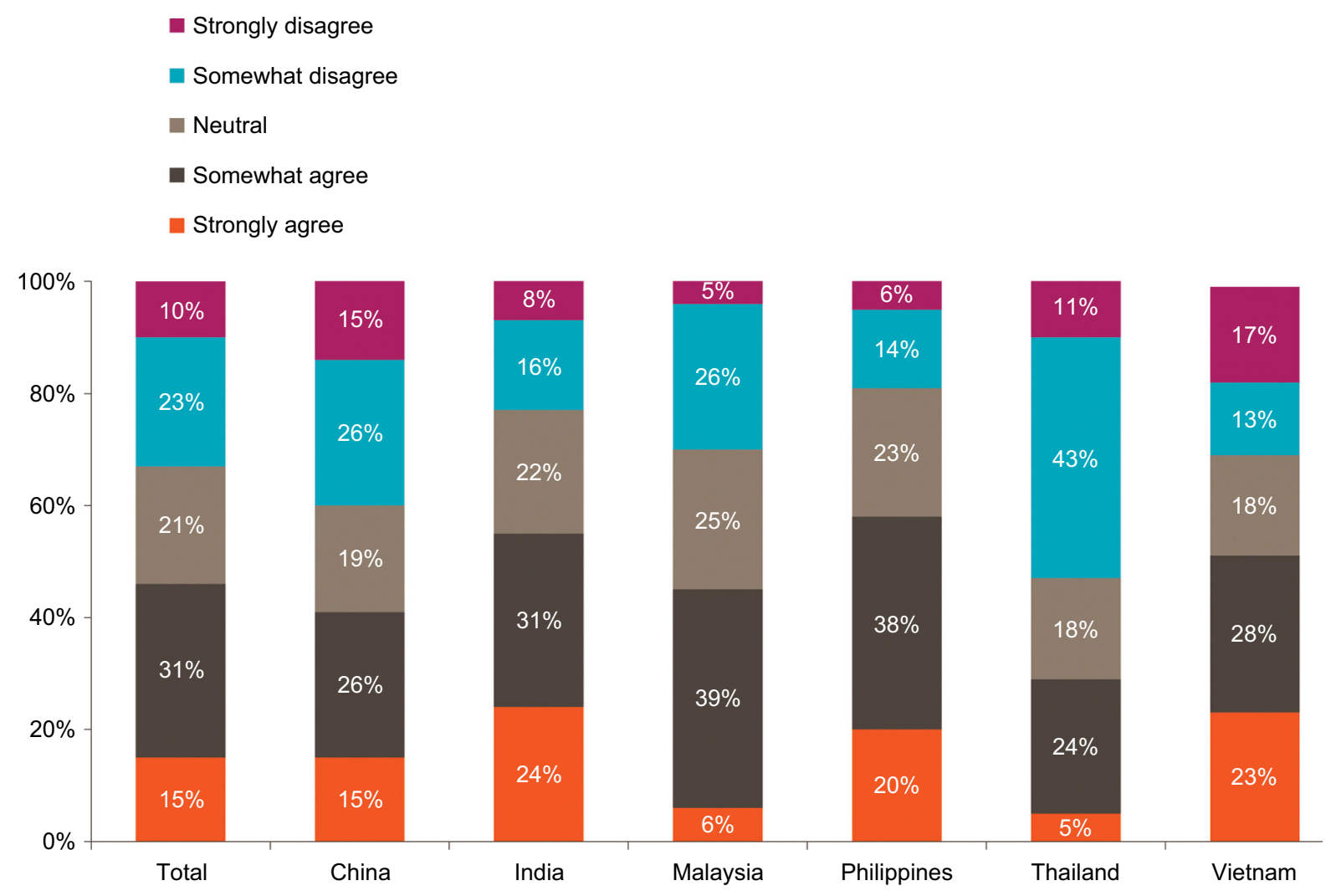

Figure 5 Physician beliefs about patients' treatment preferences.

Note: Total $(n=1,204)$, China $(n=200)$, India $(n=200)$, Malaysia $(n=202)$, Philippines $(n=200)$, Thailand $(n=200)$, Vietnam $(n=202)$. 
Table 2 Preferred treatment for coexistent asthma-AR

\begin{tabular}{|c|c|c|c|c|c|c|c|c|}
\hline & $\begin{array}{l}\text { Total } \\
\mathrm{N}=1,204\end{array}$ & $\begin{array}{l}\text { China } \\
\mathrm{N}=200\end{array}$ & $\begin{array}{l}\text { India } \\
\mathbf{N}=\mathbf{2 0 0}\end{array}$ & $\begin{array}{l}\text { Malaysia } \\
\mathrm{N}=202\end{array}$ & $\begin{array}{l}\text { Philippines } \\
\mathrm{N}=200\end{array}$ & $\begin{array}{l}\text { Thailand } \\
\mathrm{N}=\mathbf{2 0 0}\end{array}$ & $\begin{array}{l}\text { Vietnam } \\
\mathrm{N}=202\end{array}$ & $P$-value ${ }^{a}$ \\
\hline $\begin{array}{l}\text { Combination of inhaled corticosteroids } \\
\text { and intranasal corticosteroids }(P<0.00 \mathrm{I})\end{array}$ & 47 & 71 & 40 & 52 & 38 & 59 & 26 & $<0.001$ \\
\hline $\begin{array}{l}\text { Combination of oral LTRA and inhaled } \\
\text { corticosteroids }(P<0.00 \mathrm{I})\end{array}$ & 22 & 6 & 20 & 16 & 34 & 19 & 36 & $<0.001$ \\
\hline Only inhaled corticosteroids $(P<0.00 \mathrm{I})$ & 4 & 1 & 10 & $\mathrm{I}$ & 3 & 1 & 9 & $<0.001$ \\
\hline Only intranasal corticosteroids $(P<0.0 \mathrm{I})$ & 2 & 3 & 5 & 0 & 1 & 1 & 2 & $<0.01$ \\
\hline $\begin{array}{l}\text { Oral corticosteroids and oral } \\
\text { antihistamines }(P<0.01)\end{array}$ & 6 & 8 & 10 & 3 & 7 & 2 & 4 & $<0.01$ \\
\hline $\begin{array}{l}\text { Inhaled corticosteroids and oral } \\
\text { antihistamines }(P<0.001)\end{array}$ & 15 & 5 & 11 & 23 & 17 & 16 & 17 & $<0.001$ \\
\hline $\begin{array}{l}\text { Only oral/inhaled antihistamines } \\
(P<0.001)\end{array}$ & 1 & 5 & 3 & 0 & 0 & 0 & 0 & $<0.001$ \\
\hline Only LTRA (NS, $P>0.05)$ & 1 & 1 & 3 & 2 & $\mathrm{I}$ & 0 & $\mathrm{I}$ & NS \\
\hline $\begin{array}{l}\text { Other responses combined } \\
(\mathrm{NS}, P>0.05)\end{array}$ & 2 & 2 & $\mathrm{I}$ & 2 & $I$ & 4 & 0 & NS \\
\hline
\end{tabular}

Notes: ${ }^{a}$ Kruskal-Wallis Test. Values shown as \%. Q. From the following pharmacological treatments, what is your preferred treatment for a patient with coexistent asthmaallergic rhinitis? I) Combination of inhaled corticosteroids and intranasal corticosteroids. 2) Combination of oral anti-leukotrienes and inhaled corticosteroids. 3) Only inhaled corticosteroids. 4) Only intranasal corticosteroids. 5) Oral corticosteroids and oral antihistamines. 6) Inhaled corticosteroids and oral antihistamines. 7) Only oral/ inhaled antihistamines. 8) Only LTRA. Physicians may also have answered 'Other' and been asked to specify, 'Do not know' or refused to answer'.

Abbreviations: AR, allergic rhinitis; NS, not significant ( $P>0.05)$; LTRA, leukotriene receptor antagonist.

Table 3 Factors influencing treatment choice

\begin{tabular}{|c|c|c|c|c|c|c|c|}
\hline & $\begin{array}{l}\text { Total } \\
N=1,204\end{array}$ & $\begin{array}{l}\text { China } \\
\mathrm{N}=200\end{array}$ & $\begin{array}{l}\text { India } \\
\mathrm{N}=\mathbf{2 0 0}\end{array}$ & $\begin{array}{l}\text { Malaysia } \\
\mathrm{N}=202\end{array}$ & $\begin{array}{l}\text { Philippines } \\
\mathbf{N}=200\end{array}$ & $\begin{array}{l}\text { Thailand } \\
\mathbf{N}=200\end{array}$ & $\begin{array}{l}\text { Vietnam } \\
\mathrm{N}=202\end{array}$ \\
\hline Practice guidelines & 62 & 50 & 82 & 69 & 17 & 86 & 53 \\
\hline Physicians' personal experience & 49 & 63 & 85 & 49 & 8 & 56 & 22 \\
\hline Availability (in stock) & 30 & 29 & 18 & 49 & 15 & 45 & 19 \\
\hline $\begin{array}{l}\text { Treatment on the drug list or clinicl } \\
\text { insurance formulary }\end{array}$ & 19 & 31 & 13 & 27 & 0 & 20 & 20 \\
\hline Patient preference & 25 & 34 & 16 & 34 & 10 & 36 & 13 \\
\hline Patient affordability & 50 & 55 & 33 & 42 & 70 & 51 & 54 \\
\hline Other responses combined & 0 & 0 & 0 & 0 & 0 & 0 & 2 \\
\hline
\end{tabular}

Notes: Q. What factors, excluding individual patient characteristics, influence your choice of treatment? (response options not read or shown to respondents). Values shown as \%.

The estimated prevalence of asthma in patients with AR in this survey (range $28 \%-46 \%$ ) is consistent with that reported in other studies, ${ }^{3,4}$ but the prevalence of AR in patients with asthma (range $34 \%-50 \%$ ) was lower than that in studies reported elsewhere. ${ }^{3,5,6}$ This non-concordance may be related to patients who do not perceive their symptoms of AR as a disease and therefore do not come forward to be assessed and treated. ${ }^{3}$ This possible underdiagnosis of coexistent AR highlights a potential health risk for patients who are more likely to have uncontrolled asthma if they have untreated symptoms of rhinitis ${ }^{3,-11}$ and underlines the importance of physicians evaluating patients for the coexistence of either disease when one is already present and initiating appropriate management.
A key finding of this survey was the lack of agreement between physicians' acknowledgment of the guidelines and their application in clinical practice. This was particularly apparent with respect to the assessment and treatment of asthma, with $41 \%$ of surveyed physicians stating that their asthma patients are treated with a SABA alone and 59\% confirming the use of an oral LTRA as a controller medication in addition to SABAs. An overuse of quick reliever medications to treat asthma together with an underuse of inhaled controller medications has been reported previously for the Asia-Pacific region in two large global patient surveys, ${ }^{23,25}$ conducted in 2009-2011 and 2009, respectively. GINA recommends using a SABA alone for patients with mild intermittent asthma only, the frequency of which is 
estimated to occur in $<40 \%$ of the total asthma population, ${ }^{26}$ and suggests prescribing low-dose ICS for most asthma patients, even those with infrequent symptoms, to reduce the risk of serious exacerbations. ${ }^{22}$ As few physicians across countries reported monitoring the frequency of SABA use to monitor asthma control (a GINA-recommended indicator of poor control), these data could signal an underuse of ICS in some patients, a risk factor for poor asthma outcomes. ${ }^{22}$ The use of PRO tools to assess asthma control was also relatively low while approximately a fifth of physicians reported using feedback from the patient/family to assess asthma control. The recent Global Asthma Physician Survey (conducted in 2015 in Australia, Canada, China, France, Germany, and Japan) also reported a discrepancy between the measures used by physicians to assess asthma control and those recommended by GINA with less than a quarter of all physicians surveyed using the frequency of SABAs to assess asthma control and a smaller percentage utilizing PROs. $^{27}$

The majority of physicians interviewed across all countries agreed that additional medications are required to treat coexistent asthma-AR, compared with treating one condition alone (in alignment with ARIA); however, only $47 \%$ stated their preferred treatment as a combination of ICS and INS (ARIA recommendation), with particularly low use cited by physicians interviewed in Vietnam (26\%) and the Philippines (38\%). The overall and country-specific rates need to be interpreted relative to the health systems and access to medications within the surveyed countries, though these may reflect physicians' concerns regarding overall steroid burden. This is a particular possibility as approximately a quarter of physicians strongly or somewhat agreed that corticosteroid therapy to treat asthma or AR should be delayed in children. This delay is clinically important as early intervention with ICS reduces the risk of exacerbations and is associated with long-term benefits on lung growth and airway obstruction. ${ }^{22,28}$

Reassuringly, most physicians interviewed clearly recognized the impacts and increased burden of having coexistent disease vs one condition only, suggesting an understanding of the disease and its impacts on patients' everyday lives and quality of life, consistent with the evidence in the literature. ${ }^{9-16}$ This was tempered by the level of non-concordance shown with ARIA guidelines in terms of managing the coexistent disease, as well as the interesting perception that patients with asthma alone were more likely to have unplanned emergency visits or hospitalization compared with those with coexistent disease, which was common across all countries with the exception of China. This is despite evidence demonstrating that patients with coexistent asthma-AR are more likely to experience a greater number of asthma attacks requiring healthcare resources, compared with asthma alone. ${ }^{12-14}$ Another interesting finding was that $46 \%$ of physicians overall considered their patients to be well managed if either their asthma or AR improved, and this was particularly noted in physicians interviewed in India (65\%) and the Philippines (73\%), perhaps indicating a low level of understanding the true impact of one disease on the other or a poor expectation of what can be achieved through effective treatment of both the conditions. Overall, these data signal a call to action across the region to work on the promising building blocks that are already in place and to drive change by improving awareness of coexistent disease, encouraging physicians to actively look for and diagnose the disease together with the implementation of appropriate management and follow-up.

The inclusion of a generally representative sample of physicians, reflective of clinical practice across six countries, is a strength of this survey, as well as the high response rates showing a good level of engagement from the physicians approached. However, it must also be acknowledged that there may have been an over-sampling of urban vs rural physicians due to the sampling method used, and as countries in the Asia-Pacific region were represented, the reported findings may not be globally applicable in their entirety. In addition, this was a cross-sectional survey, and therefore, no conclusions about longitudinal behaviors can be derived from these results. A further important limitation may have been "social desirability bias," that is, physicians are aware of the guidelines and know that they should be following them, and so responses may reflect that. This may be particularly pertinent in the ASPAIR survey as interviews were in-person. To mitigate this, questions were spaced out during the interview to eliminate priming.

In conclusion, this large-scale survey of physicians in the Asia-Pacific region demonstrates widespread acceptance of the existence and associated burden of coexistent asthma-AR, together with an acknowledgement of the usefulness of the guidelines. However, there was a discordance between their beliefs and perceptions and their management and treatment practices with respect to applying the guideline recommendations to coexistent asthma-AR. These data highlight the need for increased healthcare practitioner awareness to improve appropriate diagnosis and management of coexistent asthma-AR, with the aim of improving outcomes and quality of life for patients. 


\section{Acknowledgments}

The authors would like to thank the ASPAIR study team who were responsible for the study oversight: Indu Khosla, Maria Isabel Atienza, Maria Cristina Balotro-Torres, Pham Le An, Tran Anh Tuan, Hooi Lai Ngoh, and Sudawan Siriaksorn.

Editorial support in the form of copyediting, collating author comments, and fact checking was provided by Kate Hollingworth of Continuous Improvement Ltd, Devon, UK, and was funded by GSK (Study 206753).

\section{Disclosure}

All the authors are GSK employees and all hold GSK shares. The authors report no other conflicts of interest in this work.

\section{References}

1. Khan DA. Allergic rhinitis and asthma: epidemiology and common pathophysiology. Allergy Asthma Proc. 2014;35(5):357-361.

2. Rimmer J, Ruhno JW. 6: Rhinitis and asthma: united airway disease. Med J Aust. 2006;185(10):565-571.

3. Bousquet J, Khaltaev N, Cruz AA, et al. Allergic Rhinitis and its Impact on Asthma (ARIA) 2008. Allergy. 2008;63(Suppl. 5):8-160.

4. Bjerg A, Eriksson J, Ólafsdóttir IS, et al. The association between asthma and rhinitis is stable over time despite diverging trends in prevalence. Respir Med. 2015;109(3):312-319.

5. Navarro A, Valero A, Juliá B, Quirce S. Coexistence of asthma and allergic rhinitis in adult patients attending allergy clinics: ONEAIR study. J Investig Allergol Clin Immunol. 2008;18(4):233-238.

6. Price D. Asthma and allergic rhinitis: Linked in treatment and outcomes. Ann Thorac Med. 2010;5(2):63-64.

7. Shaaban R, Zureik M, Soussan D, et al. Rhinitis and onset of asthma: a longitudinal population-based study. Lancet. 2008;372(9643):1049-1057.

8. van den Nieuwenhof L, Schermer T, Bosch Y, et al. Is physiciandiagnosed allergic rhinitis a risk factor for the development of asthma? Allergy. 2010;65(8):1049-1055.

9. Magnan A, Meunier JP, Saugnac C, Gasteau J, Neukirch F. Frequency and impact of allergic rhinitis in asthma patients in everyday general medical practice: a French observational cross-sectional study. Allergy. 2008;63(3):292-298.

10. Ohta K, Bousquet PJ, Aizawa H, et al. Prevalence and impact of rhinitis in asthma. SACRA, a cross-sectional nation-wide study in Japan. Allergy. 2011;66(10):1287-1295.

11. Hojo M, Ohta K, Iikura M, Hirashima J, Sugiyama H, Takahashi K. The impact of co-existing seasonal allergic rhinitis caused by Japanese Cedar Pollinosis (SAR-JCP) upon asthma control status. Allergol Int. 2015;64(2):150-155.

12. Bousquet J, Gaugris S, Kocevar VS, et al. Increased risk of asthma attacks and emergency visits among asthma patients with allergic rhinitis: a subgroup analysis of the improving asthma control trial. Clin Exp Allergy. 2005;35(6):723-727.
13. Price D, Zhang Q, Kocevar VS, Yin DD, Thomas M. Effect of a concomitant diagnosis of allergic rhinitis on asthma-related health care use by adults. Clin Exp Allergy. 2005;35(3):282-287.

14. Gaugris S, Sazonov-Kocevar V, Thomas M. Burden of concomitant allergic rhinitis in adults with asthma. J Asthma. 2006;43(1):1-7.

15. Maio S, Baldacci S, Simoni M, et al. Impact of asthma and comorbid allergic rhinitis on quality of life and control in patients of Italian general practitioners. J Asthma. 2012;49(8):854-861.

16. Braido F, Baiardini I, Menoni S, et al. Patients with asthma and comorbid allergic rhinitis: is optimal quality of life achievable in real life? PLoS One. 2012;7(2):e31178.

17. Kim CW, Lee CW, Hur GY, Ye YM, Park HS; CARINA Study Group. Evaluation and control of allergic rhinitis in adult patients with asthma (CARINA) in Korea. Korean J Asthma Allergy Clin Immunol. 2007;27(4):248-256.

18. Lin J, Su N, Liu G, et al. The impact of concomitant allergic rhinitis on asthma control: a cross-sectional nationwide survey in China. JAsthma. 2014;51(1):34-43.

19. Nga NN, Chai SK, Bihn TT, et al. ISAAC-based asthma and atopic symptoms among Ha Noi school children. Pediatr Allergy Immunol. 2003;14(4):272-279.

20. Hailu S, Tessema T, Silverman M. Prevalence of symptoms of asthma and allergies in schoolchildren in Gondar town and its vicinity, northwest Ethiopia. Pediatr Pulmonol. 2003;35(6):427-432.

21. Dennis R, Caraballo L, García E, et al. Asthma and other allergic conditions in Colombia: a study in 6 cities. Ann Allergy Asthma Immunol. 2004;93(6):568-574.

22. Global Initiative for Asthma (GINA). Global strategy for asthma management and prevention, 2017. Available from: http://www. ginasthma.com. Accessed April 30, 2018.

23. Nathan RA, Thompson PJ, Price D, et al. Taking Aim at Asthma Around the World: Global Results of the Asthma Insight and Management Survey in the Asia-Pacific Region, Latin America, Europe, Canada, and the United States. J Allergy Clin Immunol Pract. 2015;3(5): 734-742.

24. Su N, Lin J, Liu G, et al. Asthma with allergic rhinitis management in China: a nationwide survey of respiratory specialists at tertiary hospitals. Int Forum Allergy Rhinol. 2015;5(3):221-232.

25. Lai CKW, de Guia TS, Kim YY et al; on behalf of the Asthma Insights and Reality in Asia-Pacific Steering Committee. Asthma control in the Asia-Pacific region: The Asthma Insights and Reality in Asia-Pacific Study. J Allergy Clin Immunol. 2003;111:263-268.

26. Dusser D, Montani D, Chanez P, et al. Mild asthma: an expert review on epidemiology, clinical characteristics and treatment recommendations. Allergy. 2007;62(6):591-604.

27. Chapman KR, Hinds D, Piazza P, et al. Physician perspectives on the burden and management of asthma in six countries: The Global Asthma Physician Survey (GAPS). BMC Pulm Med. 2017;17(1):153.

28. Busse WW, Pedersen S, Pauwels RA, et al. The Inhaled Steroid Treatment as Regular Therapy in Early Asthma (START) study 5-year follow-up: effectiveness of early intervention with budesonide in mild persistent asthma. J Allergy Clin Immunol. 2008;121(5): $1167-1174$. 


\section{Supplementary materials}

Table SI Criteria to assess AR symptoms among asthma patients and asthma symptoms among AR patients

\begin{tabular}{|c|c|c|c|c|c|c|c|}
\hline & $\begin{array}{l}\text { Total } \\
(\mathrm{N}=1,204)\end{array}$ & $\begin{array}{l}\text { China } \\
(\mathrm{N}=\mathbf{2 0 0})\end{array}$ & $\begin{array}{l}\text { India } \\
(\mathrm{N}=\mathbf{2 0 0})\end{array}$ & $\begin{array}{l}\text { Malaysia } \\
(\mathrm{N}=\mathbf{2 0 2})\end{array}$ & $\begin{array}{l}\text { Philippines } \\
(\mathbf{N}=\mathbf{2 0 0})\end{array}$ & $\begin{array}{l}\text { Thailand } \\
(\mathrm{N}=\mathbf{2 0 0})\end{array}$ & $\begin{array}{l}\text { Vietnam } \\
(\mathrm{N}=202)\end{array}$ \\
\hline \multicolumn{8}{|c|}{ Criteria to assess AR symptoms among asthma patients ${ }^{a}$} \\
\hline History of nasal symptoms & 88 & 100 & 95 & 74 & 78 & 97 & 79 \\
\hline History of eye symptoms & 50 & 61 & 75 & 45 & 8 & 78 & 17 \\
\hline Family history of AR/atopy & 47 & 59 & 66 & 33 & 28 & 71 & 16 \\
\hline Symptoms due to seasonal allergens & 46 & 79 & 61 & 23 & 6 & 58 & 33 \\
\hline Symptoms due to recurring allergens & 33 & 41 & 50 & 24 & 0 & 59 & 10 \\
\hline $\begin{array}{l}\text { Exposure to environmental hazards/ } \\
\text { pollutants }\end{array}$ & 30 & 38 & 37 & 24 & 24 & 28 & 26 \\
\hline Skin prick or lgE testing & 14 & 17 & 25 & 6 & $\mathrm{I}$ & 26 & 3 \\
\hline $\begin{array}{l}\text { Withdraw AR treatment/start trial } \\
\text { AR treatment }\end{array}$ & 7 & 9 & 6 & 3 & 0 & 24 & 0 \\
\hline Other responses combined & 7 & 0 & 0 & 12 & 0 & 4 & 24 \\
\hline \multicolumn{8}{|c|}{ Criteria to diagnose asthma symptoms in AR patients ${ }^{a}$} \\
\hline $\begin{array}{l}\text { Clinical history of wheezing/SOB/ } \\
\text { chest tightness/cough }\end{array}$ & 91 & 100 & 94 & 87 & 78 & 100 & 82 \\
\hline Family history of asthma/atopy & 56 & 79 & 85 & 31 & 34 & 72 & 28 \\
\hline $\begin{array}{l}\text { Exposure to common asthma } \\
\text { triggers }\end{array}$ & 43 & 74 & 57 & 32 & 14 & 63 & 9 \\
\hline Lung function tests confirmation & 34 & 57 & 40 & 17 & 5 & 50 & 26 \\
\hline Reversibility/methacholine challenge & 25 & 35 & 32 & 12 & 2 & 50 & 12 \\
\hline $\begin{array}{l}\text { Withdraw respiratory treatment/ } \\
\text { start trial respiratory treatment }\end{array}$ & 4 & 1 & 6 & 1 & $\mathrm{I}$ & 16 & 0 \\
\hline Guidelines (eg, GINA, ARIA) & 2 & 0 & 0 & 12 & 0 & 0 & 0 \\
\hline Exacerbations & $\mathrm{I}$ & 0 & 0 & 0 & 0 & $\mathrm{I}$ & 4 \\
\hline Clinical examination & 2 & 0 & 0 & 0 & 0 & 1 & 13 \\
\hline Other responses combined & 5 & 0 & 0 & 2 & 0 & 3 & 22 \\
\hline
\end{tabular}

Notes: aResponses to these questions were not elicited from a predetermined list. Values shown as \%

Abbreviations: AR, allergic rhinitis; ARIA, Allergic Rhinitis and its Impact on Asthma; IgE, immunoglobulin E; GINA, Global Initiative for Asthma; SOB, shortness of breath. 
Table S2 Most common criteria used to assess asthma control in asthma patients with AR (open-ended question)

\begin{tabular}{|c|c|c|c|c|c|c|c|}
\hline & $\begin{array}{l}\text { Total } \\
(\mathrm{N}=1,204)\end{array}$ & $\begin{array}{l}\text { China } \\
(N=200)\end{array}$ & $\begin{array}{l}\text { India } \\
(N=200)\end{array}$ & $\begin{array}{l}\text { Malaysia } \\
(\mathrm{N}=202)\end{array}$ & $\begin{array}{l}\text { Philippines } \\
(\mathrm{N}=\mathbf{2 0 0})\end{array}$ & $\begin{array}{l}\text { Thailand } \\
(\mathrm{N}=200)\end{array}$ & $\begin{array}{l}\text { Vietnam } \\
(\mathrm{N}=202)\end{array}$ \\
\hline $\begin{array}{l}\text { Type and frequency of } \\
\text { symptoms }\end{array}$ & 84 & 92 & 85 & 77 & 72 & 92 & 76 \\
\hline $\begin{array}{l}\text { Frequency of nighttime } \\
\text { awakenings }\end{array}$ & 36 & 55 & 63 & 16 & 7 & 52 & 4 \\
\hline $\begin{array}{l}\text { Interference with normal } \\
\text { activities apart from work }\end{array}$ & 30 & 29 & 49 & 14 & 0 & 65 & 6 \\
\hline $\begin{array}{l}\text { Interference with work or } \\
\text { household work }\end{array}$ & 21 & 28 & 38 & 7 & 0 & 41 & 1 \\
\hline Interference with exercise & 20 & 43 & 28 & 8 & 5 & 26 & I \\
\hline $\begin{array}{l}\text { Lung function with spirometry } \\
\left(\mathrm{FEV}_{1}\right) \text { or peak flow }\end{array}$ & 18 & 32 & 45 & 12 & 4 & 3 & 4 \\
\hline Number of exacerbations & 29 & 30 & 40 & 5 & 5 & 66 & 13 \\
\hline $\begin{array}{l}\text { Validated patient-reported } \\
\text { outcomes via questionnaires }\end{array}$ & 8 & 20 & 16 & 5 & 5 & 2 & I \\
\hline $\begin{array}{l}\text { Use of reliever } \\
\text { bronchodilators for symptom } \\
\text { control }\end{array}$ & 11 & 11 & 24 & 12 & I & 9 & 5 \\
\hline $\begin{array}{l}\text { Medication use and frequency, } \\
\text { excluding SABAs }\end{array}$ & 20 & 25 & 33 & 15 & 0 & 21 & 12 \\
\hline $\begin{array}{l}\text { Medical history, including } \\
\text { number of office visits }\end{array}$ & 30 & 44 & 31 & 11 & 8 & 50 & 22 \\
\hline Patient or family feedback & 16 & 43 & 0 & 9 & 0 & 30 & 2 \\
\hline $\begin{array}{l}\text { Examination or clinical } \\
\text { evaluation }\end{array}$ & 31 & 38 & 45 & 12 & 4 & 55 & 15 \\
\hline Other responses combined & 7 & I & 0 & 0 & 0 & I & 40 \\
\hline
\end{tabular}

Note: Values shown as \%.

Abbreviations: AR, allergic rhinitis; FEVI, forced expiratory volume in I sec; SABA, short-acting beta-agonist.

Table S3 Most common criteria used to assess asthma control in asthma patients (open-ended question)

\begin{tabular}{|c|c|c|c|c|c|c|c|}
\hline & $\begin{array}{l}\text { Total } \\
(\mathbf{N}=1,204)\end{array}$ & $\begin{array}{l}\text { China } \\
(N=200)\end{array}$ & $\begin{array}{l}\text { India } \\
(\mathrm{N}=\mathbf{2 0 0})\end{array}$ & $\begin{array}{l}\text { Malaysia } \\
(\mathrm{N}=\mathbf{2 0 2})\end{array}$ & $\begin{array}{l}\text { Philippines } \\
(\mathbf{N}=200)\end{array}$ & $\begin{array}{l}\text { Thailand } \\
(\mathrm{N}=200)\end{array}$ & $\begin{array}{l}\text { Vietnam } \\
(\mathrm{N}=202)\end{array}$ \\
\hline $\begin{array}{l}\text { Type and frequency of } \\
\text { symptoms }\end{array}$ & 84 & 91 & 92 & 73 & 63 & 87 & 84 \\
\hline $\begin{array}{l}\text { Frequency of nighttime } \\
\text { awakenings }\end{array}$ & 49 & 74 & 62 & 27 & 8 & 77 & 23 \\
\hline $\begin{array}{l}\text { Interference with normal } \\
\text { activities apart from work }\end{array}$ & 34 & 38 & 49 & 13 & 0 & 72 & 10 \\
\hline $\begin{array}{l}\text { Interference with work or } \\
\text { household work }\end{array}$ & 27 & 37 & 36 & 10 & $I$ & 55 & 4 \\
\hline Interference with exercise & 33 & 57 & 32 & 22 & 8 & 58 & 5 \\
\hline $\begin{array}{l}\text { Lung function with spirometry } \\
\left(\mathrm{FEV}_{1}\right) \text { or peak flow }\end{array}$ & 32 & 58 & 47 & 11 & 11 & 42 & 11 \\
\hline Number of exacerbations & 38 & 45 & 40 & 8 & 10 & 89 & 17 \\
\hline $\begin{array}{l}\text { Validated patient-reported } \\
\text { outcomes via questionnaires }\end{array}$ & 18 & 28 & 25 & 19 & 3 & 24 & 2 \\
\hline $\begin{array}{l}\text { Use of reliever } \\
\text { bronchodilators for symptom } \\
\text { control }\end{array}$ & 30 & 22 & 30 & 24 & 5 & 73 & 9 \\
\hline $\begin{array}{l}\text { Medication use and frequency, } \\
\text { excluding SABAs }\end{array}$ & 32 & 34 & 37 & 17 & 3 & 59 & 23 \\
\hline $\begin{array}{l}\text { Medical history, including } \\
\text { number of office visits }\end{array}$ & 35 & 45 & 34 & 18 & $I$ & 54 & 36 \\
\hline Patient or family feedback & 21 & 41 & 41 & 8 & 0 & 22 & 3 \\
\hline Exam or clinical evaluation & 30 & 44 & 36 & 5 & 3 & 52 & 22 \\
\hline Other responses combined & 5 & 0 & 3 & 0 & 0 & 3 & 23 \\
\hline
\end{tabular}

Note: Values shown as \%.

Abbreviations: AR, allergic rhinitis; FEVI, forced expiratory volume in I sec; SABA, short-acting beta-agonist. 
Journal of Asthma and Allergy

The Journal of Asthma and Allergy is an international, peer-reviewed open access journal publishing original research, reports, editorials and commentaries on the following topics: Asthma; Pulmonary physiology; Asthma related clinical health; Clinical immunology and the immunological basis of disease; Pharmacological interventions and new therapies. This journal is included in PubMed. The manuscript management system is completely online and includes a very quick and fair peer-review system, which is all easy to use. Visit http://www. dovepress.com/testimonials.php to read real quotes from published authors.

Submit your manuscript here: https://www.dovepress.com/journal-of-asthma-and-allergy-journal 